\title{
Women Rarely Worthy of Study: A History of Curriculum Reform in Ontario Education
}

\author{
R. Fine-Meyer \\ OISE/University of Toronto \\ K. Llewellyn \\ Renison University College, University of Waterloo
}

\section{ABSTRACT}

The topic of women and education has historically held a strong focus in the history of education field. Feminist scholars brought together the fields of women's studies and the history of education. Their research examined the hierarchies embedded in the social structures of education departments. Such work left an important mark in the historiography of the field, but the focus on women and gender has dropped off in recent years. This is despite the fact that there is still a great deal of work that must be done to effect change. This article explores the stalled progress and even regression towards incorporating women's histories and stories in schools. We provide a case study analysis of the history of curriculum reform in Ontario from the 1960s to the present to demonstrate that over the last five decades women's issues have been squeezed into the margins of Ontario's educational learning objectives and related policy initiatives. We conclude that to support a new wave of feminist consciousness among young people, women's issues must become a mandatory and integral part of education. All women's issues, ways of knowing, historical experiences, and justice movements must be central to curricular reform.

\section{RÉSUMÉ}

Le thème des femmes et de l'éducation a toujours été un élément prédominant dans le champ de l'histoire de l'éducation. Les chercheurs féministes ont réuni les champs des études féministes et de l'histoire de l'éducation. Leurs recherches ont étudié les hiérarchies intégrées dans les structures sociales des départements de l'éducation. Bien que ce travail ait marqué l'historiographie de manière importante, l'accent mis sur les femmes et le genre a chuté au cours des dernières années. Ceci en dépit du fait qu'il reste beaucoup de travail à faire pour produire du changement. Cet article explore la stagnation, et même la régression, du mouvement vers l'intégration des femmes et de leurs histoires dans les écoles. Nous présentons une analyse de l'histoire de la réforme des programmes scolaires en Ontario des années 1960 à aujourd'hui pour démontrer qu'au cours des cinq dernières décennies, les enjeux relatifs aux femmes ont été réduits aux marges des objectifs éducatifs de l'Ontario et des initiatives politiques connexes. Nous concluons que pour soutenir une nouvelle vague de conscience féministe chez les jeunes, les enjeux relatifs aux femmes doivent devenir une partie intégrante et obligatoire de l'éducation. 
Tous les enjeux relatifs aux femmes, aux formes de savoir, aux expériences historiques et aux mouvements de justice sociale doivent être au centre de la réforme des programmes.

On January 21, 2017, tens of thousands of Canadians joined millions worldwide in a women's march. Women and their allies marched with pussy hats and gender justice signs to resist increasing misogyny, in relation to intersectional oppression, symbolized by the election of Donald Trump as president of the United States. ${ }^{1}$ Particularly striking at rallies across Canada was the cross-generational solidarity expressed against encroachments of women's rights. At a rally in St. Catharines, Ontario, for example, a fourteen-year-old girl addressed the crowd spontaneously during her first-ever rally to say that people needed to know the gender-based harassment and stereotyping faced by young women in schools. The rallying cries of young women at marches challenge any easy discursive construction of the millennial generation as post-feminist. Shauna Pomerantz and Rebecca Raby argue that standardized stories of girls' "overachievement" in schools - myths of super girls and failing boys - have served to erase the complex struggles girls face, from sexism in the classroom to gender inequality in careers. ${ }^{2}$

Canadians often laud the great successes of the gender equity revolution, including suffrage, the Person's Case, access to birth control, and parental leaves, to name but a few of the reforms that have occurred over the last hundred years. Despite the past and present successes of the gender equity revolution and ongoing lobbying by feminists, progress appears to have stalled and in many instances regressed: Canada ranks sixty-first in the world for women holding political office; women's labour force participation is falling, primarily due to barriers for immigrant women; women remain segregated out of the lucrative science, technology, engineering, and mathematics (STEM) subjects in universities; and Indigenous girls and women are three to five times more likely to experience violence than non-Indigenous women. ${ }^{3}$

We argue in this article that stalled progress and regression could be connected to the fact that women's histories and stories rarely seem to be the focus of study in schools. In this article, we provide a case study analysis of the history of curriculum reform in Ontario from the 1960s to the present. While we recognize that this provincial study does not reflect a pan-Canadian experience, we agree with Alans Sears, who argues that there are subtle nationalist agendas for curriculum design, particularly for social studies education. ${ }^{4}$ We demonstrate that over the last five decades women's issues have been squeezed into the margins of Ontario's educational learning objectives and related policy initiatives, despite activism and resources by feminist scholars and educators. We conclude that to support a new wave of feminist consciousness among girls and boys - young people who will march against misogyny — women's issues must be a mandatory and integral part of education.

\section{Second-wave Feminism and the Curricular Void}

The second-wave feminist movement, which unfolded between the early 1960s and the 1980s, had as its overarching goal equality between women and men. As Judith 
Lorber notes, feminists concentrated on “increasing women's legal rights, political representation, and entry into professions dominated by men." ${ }^{5}$ Other feminists worked to eliminate sexual harassment and sexual violence, and still others explored the use of language and knowledge to deconstruct patriarchy. The women's movement shone a particular light on the ways in which women were disadvantaged within education systems, from lack of equal pay for women educators to gendered curricula for students. In 1966, the Canadian Federation of University Women (CFUW) formed the Committee for the Equality of Women in Canada (CEW) and called on the federal government to establish a royal commission to investigate and report on the status of women. ${ }^{6}$ The Royal Commission on the Status of Women in Canada (RCSW) issued a report in 1970 that contained numerous recommendations aimed at strengthening women's position in Canada. Of the 167 recommendations made in the RCSW report, approximately 60 spoke directly to the provincial legislatures and thus required consultation with provincial groups. The Ontario Committee on the Status of Women was established to provide recommendations to the federal commission. With respect to education, the committee reported that female children in schools were taught "to accept unequal treatment and unequal status." nine of the RCSW final report confirmed that women's voices were marginalized or omitted from education materials and curricula. ${ }^{8}$ The report recommended "that the provinces and territories adopt textbooks that portray women, as well as men, in diversified roles and occupations."

The Ontario government reviewed these recommendations and in 1973 produced a green paper entitled Equal Opportunity for Women in Ontario: A Plan for Action. ${ }^{10}$ This policy statement endorsed the need for a provincial status of women council and outlined specific concerns regarding education issues. Ontario education officials responded with gender equity policies and affirmative action policies (later called employment equity policies) and by more broadly bringing gender inequality to the forefront within school boards. In 1977, the Toronto Board of Education, like a number of other school boards, called for a plan of action and affirmative action advisors. Action plans were developed related to inequities in staffing, administration or positions of added responsibility, and curriculum. The province planned for conferences and resources to be developed by the Women's Bureau of Ontario and the Ontario Women's Directorate. ${ }^{11}$ Research studies exposed ongoing issues of gender stereotyping in textbooks and other learning resource materials. The report of the Royal Commission on the Status of Women in Canada noted that: "The Commission deplores the use of textbooks that provide so little recognition of the capabilities of women." 12 A study thus followed, conducted by the Status of Women, which found that textbooks traced thousands of years of world history with little reference to women. In response, the Ontario Ministry of Education and the Ontario Association for Curriculum Development held the "Sex Role Stereotyping and Women's Studies Conference" at Queen's Park in Toronto during the fall of $1978 .{ }^{13}$ That same year, the Ontario Ministry of Education published the Sex-role Stereotyping and Women's Studies Resource Guide, and in the following year published a report entitled Today and Tomorrow, which assessed the progress of equal opportunity policy initiatives. 
Additional women's studies resources soon followed. ${ }^{14}$ Another conference sponsored by the Women's Studies Department of the Toronto Board of Education took place in the spring of 1979. Called "Free to Choose," it focused on women's human rights and education. Publications soon followed this event as well, such as $A$ Non-Sexist Bibliography (1982). ${ }^{15}$ This publication, produced by the Women's Studies Department of the University of Toronto, reviewed fictional, biographical, and reference books in which females had significant roles.

Despite some efforts to address gender equity in education policy, and curricula in particular, change was slow. Textbooks in the 1980s continued to make only token references to women. Beth Light, Pat Staton, and Paula Bourne surveyed sixty-six authorized history textbooks published during the 1980s and found that none of them met the new sex equity policies of the Ontario Ministry of Education. They determined that only 12.8 per cent of history textbooks included any reference to women. These statistics included even passing references such as "Elizabeth Simcoe had accompanied her husband to Canada." ${ }^{16}$ As a result of this research, and other studies that clearly showed learning materials contravening gender equity policy, course materials were developed in a number of subject areas, including computer studies, science, physical education, and the humanities. ${ }^{17}$ These materials were, however, supplemental to the authorized and purchased textbooks used in most classrooms that provided a masculinist, colonial narrative.

By the mid-1980s, the Ontario Ministry of Education and local school boards had published support documents to assist teachers in translating "sex equity policies" into classroom practice. ${ }^{18}$ For the most part, however, teachers were left to research and develop their own materials. Some teachers took the lead in creating what were locally-developed, individual, stand-alone courses, usually offered within one school, that focused on the experiences of women. Several of these courses were offered in Toronto secondary schools during this period with the support of the Toronto school board. The majority of locally-developed courses contained two parts: women's history units and women's contemporary issues. For example, "Women and Society" was one of the first women's studies courses that was offered as a full grade 12 credit at a north Toronto school in 1981-82. ${ }^{19}$

Many of the teachers who offered locally-developed courses had public links to feminist activism and had studied at universities where women's studies courses were emerging. Such courses grew out of women's studies and history courses that were increasingly offered at Canadian universities throughout the 1970s and early 1980s. The University of Toronto had one of the first women's studies course offered by Jill Ker Conway and Natalie Davis in $1971-1972 .^{20}$ The doors were slowly opening to the development of full women's studies departments. The Women's Studies program in the Faculty of Arts at York University offered its first official courses in $1983 .{ }^{21}$ By the 1980s, scholarship on women in Canada focused on economic, political, and social stories, exploring women and work, families, home and child-rearing. University textbooks, such as Canadian Women: A History (1988), reflected this relatively new scholarship. ${ }^{22}$ Some educators were bringing this material into their secondary school classrooms. 


\section{Gender Equity Policies: Here by the '80s, Gone by the '90s}

Curriculum documents, policy circulars, and resources were revised by the late 1980s, with school boards in Ontario removing discriminatory language from and adding women to resource materials. ${ }^{23}$ Curricula were not, however, transformed. Learning objectives and resources remained androcentric, with added sections that included women. Despite the shift in higher education, which saw women's studies and history become more accepted throughout the 1990s, history courses in public schools continued to focus predominantly on military and industrial narratives. Such an "add and stir" approach to women in history has been heavily criticized by scholars across the country. For example, Denyse Baillargeon argues that women do not just add more to our understanding of Quebec's past, rather, they provide different perspectives and complexities. ${ }^{24}$ Nancy Sheehan, among others, showed that well into the 1990s there was gender segregation within curricula. Her research specifically demonstrated a lack of acknowledgement in texts of the political achievements of women in Canada's West and the re-inscription of women's work as narrowly familial. ${ }^{25}$ Rebecca Coulter, reflecting on a growing research and policy gap regarding women's issues in schools, argued that state priorities for women were simply "to accommodate within existing state arrangements and liberal notions of equality of opportunity." 26

Even such temperate accommodation for gender equality waned in the late 1990s. There was an assault on the nominal progress made for gender justice in Ontario curricula with the election of the Conservative Mike Harris government in 1995. The conservative government, fully supportive of a neo-liberal agenda, made individualism and personal responsibility the dominant tropes for learning, thereby negating gender and intersectional power relations as critical determinants of educational success. The "Common-Sense Revolution," as it was touted by the Conservatives, included "back to basics" curricula, top-down controls over teachers, and drastic funding cuts to public schools. ${ }^{27}$ The Harris government repealed sections of the Education Act and the Employment Equity Act, which resulted in the removal of equity officers for the province's schools. ${ }^{28}$ The Conservative government did not see that particular groups, such as women and visible minorities, "experienced discrimination or exclusion in a systemic way" and, as such, did not see how massive cuts to education budgets put stress on equity initiatives in the province. ${ }^{29}$ The rise of the Right in politics played a powerful force in redirecting gender equity work on many fronts.

Small publishers and women's organizations fought back. Women's Press, Garamond Press, New Hogtown Press, Green Dragon Press, House of Anansi Press, and Second Story Press were some of the small presses that made a concerted effort to get materials about women into the hands of educators in Ontario well into the 2000s, many of them sold through the Toronto Women's Bookstore. For example, Margie Wolfe of Women's Press worked to bring books and learning resource materials to the attention of teachers in schools. She recalls that Women's Press books such as A Harvest Yet to Reap: A History of Prairie Women and Never Done: Three Centuries of Women's Work in Canada were popular with teachers and led to the development 
of teacher guides from the 1980s onwards. Other scholarship that made its way into schools included Micheline Dumont-Johnson's Québec Women: A Historyl L'Histoire des femmes au Québec depuis quatre siècles (1987) and Charlene Gannage's Double Day, Double Bind: Women Garment Workers (1986). ${ }^{30}$ These independent presses were intent on supporting the voices of Indigenous women with publications such as Enough Is Enough: Aboriginal Women Speak out (1992) and Iskwewakkah' ki yaw ni wahkomakanak: Neither Indian Princesses nor Easy Squaws (1995). ${ }^{31}$ By 2004, Unfolding Power, a publication issued by Green Dragon Press, became the first resource book designed specifically for the mandatory grade 10 history course to provide diverse primary document evidence of women's historical experiences in the twentieth century. ${ }^{32}$ Although often left out of officially approved government resource lists, independent presses still found a place within classrooms because of grassroots networking with educators. ${ }^{33}$

Scholarship in women's history in Canada expanded at this time, as reflected in the appearance of new bibliographies in the late 1990s, such as Diana Lynn Pedersen's Changing Women, Changing History: A Bibliography of the History of Women in Canada. ${ }^{34}$ She argued that interest in the field was obviously expanding as illustrated by the growth of women's history conferences, electronic networking, and new publications. Women's history organizations, such as the Ontario Women's History Network, held annual conferences throughout the 1990s and 2000s at which teachers gathered resources for their classrooms. The Canadian Committee on Women's History, the largest subgroup of the Canadian Historical Association, also made links between scholars in the field and teachers in schools in order to ensure that women's historical experiences shaped public consciousness. In many ways, these women's networks still provide an essential link for educators, who continue to bear the burden of accessing outside resources to supplement traditional curriculum documents and school textbooks. ${ }^{35}$

Such resource sharing was also possible because feminist education scholars had established a firm foundation of research exploring women as students and teachers by the 1990s. To name but two, the collection of essays Women and Education, and Rethinking Canada: The Promise of Women's History broadened the field by examining women as teachers, in academia, and in educational curricula. ${ }^{36}$ As these and other publications indicate, feminist theories and identity politics during the end of the twentieth century began to acknowledge that women's voices were not unified, rather, they included intersecting hierarchies of gender in relation to race, class, ethnicity, and more. Wendy Kohli argued that "the feminist solidarity politics of the early second wave were no longer as persuasive: class, race, ethnicity, and sexuality provided for a more complicated, disrupted view of women and women's experiences." ${ }^{37}$ And formally marginalized voices found space in the curriculum as well, as the experiences of colonization and the impact of post-colonial systems resulted in a greater recognition of Indigenous and racialized women's experiences. Collections such as 'We're Rooted Here and They Can't Pull Us Up,' with chapters by Peggy Bristow, Dionne Brand, Linda Carty, Afua P. Cooper, Sylvia Hamilton, and Adrienne Shadd, as well as books and films that contained biographical sketches of 
prominent Canadian women (for example, Nellie McClung, Agnes MacPhail, and Pauline Johnson) were added to school library collections; these works recognized how methods such as oral histories and biographies helped history educators access more diverse narratives for their classrooms. ${ }^{38}$ As Adele Perry has argued, "gender and the related categories of sexuality, family, intimacy and the body matter to history writ large, not simply to women," adding that, "conventional historical methodology has genuine limits when it comes to excavating the histories of Indigenous peoples and women." ${ }^{39}$ New narratives challenging traditional narratives about gender and nation were slowly emerging in schools by the turn of the millennium, thanks to alternative historical methodologies.

\section{From Women to Gender: Optional Learning}

By the early 2000s, it was clear that a meaningful focus on gender equity in Ontario schooling would require a change in government. The Liberals took office in 2003 and the Ministry of Education was led by Kathleen Wynne, a former public school trustee and gender equity advocate. In 2009, the minister joined a well-represented group of educators to present a panel at the humanities Congress entitled "Moving from Promise to Practice: Transforming School Curriculum to Include Women's Studies and Gender Equity in Ontario High Schools." 40 This meeting was intended to address the lack of women's full representation within curricula for over forty years. At the same time, a group of undergraduate students from Western University created a group called Miss G for Equity in Education to lobby the ministry to develop a women's studies course for secondary schools similar to their own gender studies classes at university. "Miss G" was selected as the name for this group because it was the pseudonym for a woman identified by Dr. Edward Clarke in his book Sex and Education (1873), who he indicated had successfully graduated from university, but who died early due to the "taxation of study on her brain." ${ }^{11}$ Gender studies courses and institutes were increasingly being launched at universities. Gender studies replaced the title "women's studies" in many institutions in an effort to challenge the essentialized woman and to give attention to the social constructs of femininity in relation to masculinity and intersecting oppressions of race, class, sexuality, religion, and more. ${ }^{42}$ Whether called gender or women's studies, the intent was to expand the Eurocentric, middle-class lens of the subject. This critical expansion of the study of women's issues was not, however, mirrored within Ontario public schools.

The expectation of women's groups was that Minister Wynne-a vocal feminist - would finally be the one to take bold steps in transforming the curricula. The time seemed right to combine decades of scholarship and activism in the field with curriculum development in Ontario. The government hired a team of teachers to write a gender studies course for the secondary level. This occurred at the secondary level because it had greater curricular flexibility compared to elementary social studies. The teachers selected for this task had developed or instructed stand-alone women's studies courses in the past and were vocal advocates for gender equality. They later noted that the course shell was pre-developed and they were tasked only 
with reworking the course over a few weeks in the summer of 2009.43 The teachers argued that the writing process was highly regulated and that their input had a limited impact on the final version of the new curriculum. Gender Studies, released in 2013 under the umbrella of the social sciences and humanities curriculum, was one of four new equity courses offered at the grade 11 level. The course invites students to understand the meaning of gender identity and norms of femininity and masculinity. The course also allows students to become familiar with gender concepts (for example, hypermasculinity and two-spirited); to examine gender in media, popular culture, and literature (from advertisements to films by Deepa Mehta); and to describe women's rights issues (for example, from pay equity to gender-based violence). ${ }^{44}$

What the course does not offer is an opportunity to explore the specific experiences of women. Similar to the debates in universities, the ministry decided that the broader lens of gender, rather than women, was warranted. ${ }^{45}$ The course moves beyond the whitewash of second-wave feminism to address indigeneity and non-binary gender identities. At the same time, however, the course often negates the oppression of women at the hands of men with a kind of journalistic approach to "seeing both sides." To name but a few examples, the course addresses misogyny and misandry on equal footing, hypermasculinity in relation to hyperfemininity, and provides a section on women's movements followed by one on men's movements (including men's liberation movements, which by all accounts could include men's rights advocates). ${ }^{46}$ The oppression of women and non-binary genders is detached from an analysis of systemic patriarchy. In order to ensure an opportunity for students to engage in a critical analysis of systemic patriarchy, teachers and administrators require support for this course that does not seem readily available to date. In addition, given that this is one elective in a packed slate of mandatory grade 11 courses, engagement in such critical analyses seems less likely.

Beyond this new course, implementing women's narratives within mandatory courses in Ontario secondary schools has continued to prove difficult. A new history curriculum was published in 2013, which was part of the broader revision of the Social Sciences and Humanities curriculum. The revised history guidelines focus on what has emerged in recent years as a new approach to history education - teaching students to think historically or the development of students' inquiry skills from a disciplinary perspective. ${ }^{47}$ Peter Seixas and Penney Clark have been at the forefront of this pedagogical movement in Canada. They developed, with others, the Historical Thinking Project and The History Education Network. (THEN/HiER), which has influenced curriculum reforms across the country. ${ }^{48}$ The expectation is that historical thinking skills will provide opportunities for greater critical analysis of grand, national narratives, including their masculinist characteristics. There are no studies to date that demonstrate how historical thinking skills will support an explicit gender analysis of historical narratives in Canada. Will such a disciplinary approach support feminist consciousness in its application? Does such a disciplinary approach have its own Western, masculinist traditions that may undermine gender analysis of the past? These are the questions that history education scholars are only beginning to pursue. ${ }^{49}$ 
With respect to content, a cursory analysis of the revised 2013 (grades 9 and 10) and 2015 (grades 11-12) Ontario curricula finds that women remain only scattered through the document and that there is limited attention to the deconstruction of masculinist histories. Learning expectations in the document are expressed through the language of the "role of women." As such, the focus of the document is on women's inclusion, the "contributions of women," and "the perspectives of various ethno-cultural, religious, and racial communities." ${ }^{50}$ These general references assume that teachers will have the time and resources to broaden traditional narratives. This is challenging since timelines in current textbooks remain fairly consistent with earlier texts in which women are considered in terms of their support for men and families, within a clear division of labour. While the grade 10 mandatory history course includes a wide range of women's historical experiences, the focus on women's "contributions," "changing roles," and "turning points" continues to place women's historical narratives as adjunct to the main text. For example, in an overview of the 1914-1929 content strand in the grade 10 history course, the curriculum document asks about women in relation to a military timeline: "Was this period a turning point for women in Canada?" and what was "women's contribution to the war effort, their expanding role in the workplace, and the impact of these on their role in the family and in society?" 51 Women's place in the curricula remains optional; students can elect or not to enrol in gender studies and teachers may opt in or out of expanding upon the masculinist history curricula found in other grades.

\section{Conclusion}

A historical review of curricular reforms in Ontario, particularly at the secondary level, over more than fifty years shows that despite promising pushes for reform, the struggle for gender equity in curricula has resulted in only minor changes. In the early second-wave feminist era, educators challenged basic gender stereotyping. By the 1990s, feminist educators argued for transformative curricular frameworks. By the early 2000s, secondary schools had the option of providing a course on gender studies. For decades now, women have been establishing networks for resource-sharing among feminist scholars and educators, and women have been participating in government commissions and curricular reform panels. While incremental change has occurred over these decades, reform to make women's distinct experiences of systemic patriarchy, inclusive of intersectional oppression, the cornerstone of learning has not come to fruition. This is despite women's organizing, activism, and depth of scholarship that has worked to place women's knowledge at the centre of education.

Feminist curricular reform has not occurred to the extent needed to address the increased misogyny of our contemporary culture. Given gender-based violence and attacks on women's human rights, our schools face a pressing challenge to develop a curriculum that will raise the feminist consciousness of all students. To do so will require that educators take a more fundamental assessment of the historically-entrenched, patriarchal, bureaucratic structures of schooling. While these structures are multi-faceted and beyond the scope of this paper, at the most basic level schools 
must confront the fact that men continue to manage schools and curriculum through political and corporate powers, while women are responsible for teaching and for implementing the authorized curriculum. ${ }^{52}$ Furthermore, instead of offering a rearrangement of options, which has made women rarely worthy of study, schooling requires a new women's movement of its own. Such a movement must demand feminist leadership from all genders in the education system. In so doing, such a movement must challenge the ongoing neo-liberal agenda of Ontario schooling, from standardized testing to a focus on personal responsibility as civic engagement. ${ }^{53} \mathrm{~A}$ hopeful sign is the current movement led by Indigenous scholars, educators, and activists in Ontario and across Canada to transform curricula based on Indigenous knowledges and histories. Schools are starting to create strong partnerships with First Nations to ensure that teaching and learning reflects Indigenous knowledges and practices. By embracing these changes to the curricula, educators have an opportunity to alter Western frameworks that celebrate competition and individualism and replace them with a relational pedagogy. As Brittany Luby and Kathryn Labelle note, Anishinabek education focuses on cooperative knowledge-building, where oral testimonies and stories provide a new foundation and framework for understanding. ${ }^{54}$ It is such community-based pedagogies and methodologies that will push for systemic and structural changes towards gender equity in the classroom. ${ }^{55}$ To support a new wave of feminist consciousness among girls and boys - young people who will march against misogyny — all women's issues, ways of knowing, historical experiences, and justice movements must be a mandatory and integral part of curricular reform. ${ }^{56}$

\section{Additional Readings}

Bennett, Judith M. History Matters: Patriarchy and the Challenge of Feminism. Philadelphia: University of Pennsylvania Press, 2006.

Carstairs, Catherine and Nancy Janovicek, eds. Feminist History in Canada: New Essays on Women, Gender, Work, and Nation. Vancouver: UBC Press, 2013.

Coulter, Rebecca Priegert and Helen Harper, eds. History Is Hers: Women Educators in Twentieth Century Ontario. Calgary: Detselig, 2005.

Gleason, Mona, Adele Perry, and Veronica Strong-Boag, eds. Rethinking Canada: The Promise of Women's History, 4th ed. Toronto: Oxford University Press, 2002.

Llewellyn, Kristina R. Democracy's Angels: The Work of Women Teachers. Montreal and Kingston: McGill-Queen's University Press, 2012.

Ontario History 107, no. 1 (Spring 2015), Special issue on Women and Education. Guest editor, Rose Fine-Meyer. Alison Norman, Six Nations Women Teachers at Grand River in the early Twentieth Century; Kate Zankowicz, In Search of Ruth Home: The Untold History of Museum Education at the Royal Ontario Museum; R.W. Sandwell, Re-Educating Ontario Women for the Modern Energy Regime, 1900-1940; Brittany Luby \& Kathryn Labelle, Cooperative Education at the Day School on Dalles 38C Indian Reserve, 1890 1910; Funke Aladejebi, Black Female Educators and Resistive Pedagogies, 1960s-1980s. 
Pomerantz, Shauna and Rebecca Raby. Smart Girls: Success, School, and the Myth of PostFeminism. Oakland, CA: University of California Press, 2017.

Smyth, Elizabeth M. and Paula Bourne, eds. Women Teaching, Women Learning: Historical Perspectives. Toronto: Inanna Publications, 2006.

\section{Notes}

1 See, for example, "Thousands Across Canada Rally in Support of Women's March on Washington," Globe and Mail, January 21, 2017, http://www.theglobeandmail.com/ news/national/events-organized-across-canada-to-support-washington-womens-march/ article33696331/.

2 Shauna Pomerantz and Rebecca Raby, Smart Girls: Success, School, and the Myth of Post-Feminism (Oakland, CA: University of California Press, 2017). See also Shauna Pomerantz, Rebecca Raby, and Andrea Stefanik, "Girls Run the World? Caught Between Sexism and Postfeminism in the School," Gender \& Society 27, no. 2 (2013): $185-207$.

3 Neil Guppy and Nicole Luongo, "The Rise and Stall of Canada’s Gender-Equity Revolution," Canadian Review of Sociology/Revue canadienne de Sociologie 52, no. 3 (2015): 241-265. See also Native Women's Association of Canada, Fact Sheet: Violence Against Aboriginal Women, https://nwac.ca/wp-content/uploads/2015/05/Fact_Sheet_ Violence_Against_Aboriginal_Women.pdf.

4 Alan Sears, "Instruments of Policy: How the National State Influences Citizenship Education in Canada," Canadian Ethnic Studies 29, no. 2 (1997): 1-22.

5 Judith Lorber, Gender Inequality: Feminist Theories and Politics, 4th ed. (New York: Oxford University Press, 2010), 1-4.

6 In 1990, the Ontario provincial government passed legislation requiring major employers to re-evaluate jobs to ensure women were receiving "equal pay for work of equal value." For a detailed chronology, see Lorna Marsden, Canadian Women and the Struggle for Equality (Don Mills, ON: Oxford University Press, 2012). From 1967 to 1970, Prime Minister Lester B. Pearson's government established the Royal Commission on the Status of Women in Canada, which was chaired by Florence Bird.

7 Ontario Committee on the Status of Women, "The Status of Women in Ontario," a submission to the Ontario government, March 9, 1972, 2, https://yorkspace.library. yorku.ca/xmlui/bitstream/handle/10315/2715/B1972-1\%20The\%20Status\%20of\%20 Women\%20in\%20Ontario.pdf?sequence $=1$ \&isAllowed $=y$

8 Report of the Royal Commission on the Status of Women in Canada (Ottawa: Information Canada, 1970), http://epe.lac-bac.gc.ca/100/200/301/pco-bcp/commissions-ef/ bird1970-eng/bird1970-eng.htm.

9 Ontario Status of Women, "The Status of Women in Ontario," 4.

10 Ontario Secretariat for Social Development, Equal Opportunity for Women in Ontario: A Plan for Action (Toronto: Ontario Secretariat for Social Development, 1973); Ontario Committee on the Status of Women, "The Status of Women in Ontario," 11.

11 See Joan Sangster, "Women Workers, Employment Policy and the State: The Establishment of the Ontario Women's Bureau, 1963-1970," Labour/Le Travail 36 (Fall 1995): 119-145. The Women's Bureau of Ontario was established within the Ministry of Labour and acted to improve the status of women in the workforce through research and public education. The Ontario Women's Directorate published reports and resources related to women. Across the province, the Ministry of Education partnered with provincial teacher's federations, school boards, women's directorates, and women's groups to develop resources about women. 
12 Report of the Royal Commission on the Status of Women in Canada (Ottawa: Information Canada, 1970), ch. 3, "Education," section 53, 175.

13 Ontario Association for Curriculum Development (OASD), "Sex Role Stereotyping and Women's Studies Conference," report on a conference held September 28-30, 1978; OASD, Sex-role Stereotyping and Women's Studies: A Resource Guide (Toronto: OASD, 1979).

14 Ontario Ministry of Education, Ontario Report: Today and Tomorrow (Toronto, August 15, 1979). See also Toronto District School Board Museum and Archives (hereafter TDSBMA), file Curriculum-Women's Studies, Women's Studies Toronto Board of Education: Curriculum Department Resources Available, revised 1979. See also Ontario Ministry of Education, Girls and Women in Society: Resource List (Toronto: Ontario Ministry of Education, 1977); Rolly Fobert and Patricia Kincaid, Explore and Develop: Integrating the Study of Women into the Curriculum, report on a conference held October 21-23, 1976 (Toronto: Ontario Ministry of Education and Toronto Board of Education, 1977). It should be noted that some of the first materials came out of the BC Teachers' Federation. Many of these classroom materials could be found in resource centres and libraries in Ontario. Some include Famous Canadian Women, Early Canadian Women, and From Captivity to Choice: Native Women in Canadian Literature. In 1971, the Corrective Collective published She Named It Canada: Because That's What It Was Called (Vancouver: Press Gang, 1971); copies of this book were available throughout the Toronto Board of Education.

15 TDSBMA, file EOO, envelope \#4, A Non-Sexist Bibliography, published by the school board's Women's Studies Department (Fall 1982).

16 Beth Light, Pat Staton, and Paula Bourne, "Sex-Equity Content in History Textbooks," History and Social Science Teacher Journal 25, no. 1 (1989): 18-21.

17 See, for example, Susan Wright and Andrew Griffith, About Face: Is Anybody Out There Listening? A Study of Sexism in a Secondary School (Toronto: Ontario Status of Women Council, 1978); Ontario Ministry of Education, One Step at a Time: Educational and Career Explorations (Toronto: Ontario Ministry of Education, 1984). A. McLaren and J. Gaskell, "Now You See It, Now You Don't: Gender as an Issue in School Science," in Gender In/forms Curriculum: From Enrichment to Transformation, ed. Jane Gaskell and John Willinsky (Toronto: OISE Press, 1995); Marg Wells, "From Margin to Centre: Interventions Supporting Gender Equity in the Toronto Board of Education," Women's Studies International Forum 19, no. 4 (1994): 371-38; J. Blackmore and J. Kenway, "Changing Schools, Teachers and Curriculum: But What about the Girls?" in Discourse and Power in Educational Organizations, ed. D. Corson (Toronto: OISE Press, 1995). See also Rebecca Priegert Coulter, "Gender Equity and Schooling: Linking Research and Policy," Canadian Journal of Education 21, no. 4 (1996).

18 Women's Studies, Curriculum and Staff Development Services, Board of Education for the City of North York, Sex Equity in Elementary Education: Bridging the Gap (North York: North York Board of Education, 1984).

19 See, for example, TDSBMA, file Toronto Women's Education News, 1, no. 2 (December 1981); TDSBMA, Guidelines for Observing the Women's Studies Program and Family Studies Program: Intermediate and Senior Divisions, Grades 9-13, History Collection, 1982; Patricia Kincaid, “The Long Term Effects of Women's Studies," School Guidance Worker 3, no. 1 (September-October 1975): 25-27.

20 See, for example, Wendy Robbins, Meg Luxton, Margrit Eichler, and Francine Descarries, eds., Minds of Our Own: Inventing Feminist Scholarship and Women's Studies in Canada and Quebec, 1966-76 (Waterloo, ON: Wilfrid Laurier University Press, 2008), and Jill Ker Conway, True North: A Memoir (Toronto: A. A. Knopf Canada, 1994). 
21 York University, Women's Studies, http://cfr.info.yorku.ca/files/2011/09/WomensStudies-Timeline-FEB-19.pdf. See also the history of Women's and Gender Studies et Recherches féministes (WGSRF) under the name Canadian Women's Studies Association/l'Association canadienne des études sur les femmes since its inception in the early 1980s, http://www.wgsrf.com; Kay Armitage, "Blood on the Chapel Floor: Adventures in Women's Studies," in Minds of Our Own, ed. Robbins, Luxton, Eichler, and Descarries.

22 See, for example, Catherine Carstairs and Nancy Janovicek, eds., Feminist History in Canada: New Essays on Women, Gender, Work, and Nation (Vancouver: UBC Press, 2013); Gail Cuthbert Brandt, Canadian Women: A History, 7th ed. (Toronto: Nelson, 2011); Sharon Cook, Lorna McLean, and Kate O’Rourke, Framing Our Past: Canadian Women's History in the Twentieth Century (Montreal and Kingston: McGill-Queen's University Press, 2001).

23 North York Board of Education, Sex Equity in Elementary Education.

24 Denyse Baillargeon, A Brief History of Women in Quebec, trans. W. Donald Wilson (Waterloo, ON: Wilfrid Laurier University Press, 2014).

25 Nancy M. Sheehan. "Women and Education in Alberta: The Rhetoric and the Reality," in Exploring Our Educational Past, ed. Nick Kach and Kas Mazurekeds (Calgary: Detselig, 1992). See also R. Fine-Meyer, "A Reward for Working in the Fields and Factories': Canadian Women's Suffrage Movement as portrayed in Ontario Texts, 1916-2016," in A World of Changes: The Right to Vote, The Right to Fight, The Right to Care (Association of Canadian Studies/Association d'études canadiennes, Canadian Issues, Fall 2016). See also Elizabeth Smyth, "A Noble Proof of Excellence': The Culture and Curriculum of a Nineteenth-Century Ontario Convent Academy," in Gender and Education in Ontario: An Historical Reader, ed. Ruby Heap and Alison Prentice (Toronto: Canadian Scholars' Press, 1991), 273-293; E. Smyth, "Developing the Powers of a Youthful Mind: The Evolution of Education for Young Women at St. Joseph's Academy in Toronto," Canadian Catholic Historical Studies 60 (1993):103-124 and 289.

26 Rebecca Priegert Coulter, "Gender Equity and Schooling: Linking Research and Policy," Canadian Journal of Education 21, no. 4 (1996): 433-452.

27 See R. D. Gidney, From Hope to Harris (Toronto: University of Toronto Press, 1999); Clara Morgan, "A Retrospective Look at Educational Reforms in Ontario," Our Schools, Our Selves 15, no. 2 (Winter 2006): 127-141.

28 Rebecca Coulter, "School Restructuring Ontario Style: A Gendered Agenda," in Teacher Activism in the 1990s, ed. S. Robertson and H. Smaller (Toronto: Lorimer, 1996), 94-95.

29 Ibid., 95.

30 Canadian Women's Educational Press, later known as Women's Press, was Canada's oldest English-language feminist publisher, founded under collective ownership in 1972. (Files are currently held at the Canadian Women's Movement Archives at the University of Ottawa). Linda Rasmussen, A Harvest Yet to Reap: A History of Prairie Women (Toronto: Women's Press, 1976); The Corrective Collective, Never Done: Three Centuries of Women's Work in Canada (Toronto: Canadian Women's Educational Press, 1974); Micheline Dumont-Johnson, Québec Women : A History/ L'Histoire des femmes au Québec depuis quatre siècles (Toronto: Women's Press, 1987); Charlene Gannage, Double Day, Double Bind: Women Garment Workers (Toronto: Women's Press, 1986); and more recently, Helen Lenskyj, A Lot to Learn: Girls, Women and Education in the 20th Century (Toronto: Women's Press, 2005).

31 Janet Silman, ed., Enough Is Enough: Aboriginal Women Speak Out (Toronto: Women's Press, 1992); Janice Acoose (Misko-Kìsikàwihkwè: Red Sky Woman), Iskwewakkah' ki yaw ni wahkomakanak: Neither Indian Princesses nor Easy Squaws (Toronto: Women's Press, 1995). 
32 Pat Staton, Rose Fine-Meyer, Stephanie Gibson, Unfolding Power: Documents in 20th Century Canadian Women's History (Toronto: Green Dragon Press, 2004).

33 Interview with publisher Margie Wolfe, Toronto, 2010. For a full discussion, see Rose Fine-Meyer, "Including Women: The Establishment and Integration of Canadian Women's History into Toronto Ontario Classrooms, 1968-1993" (PhD diss., University of Toronto, 2012).

34 Diana Lynn Pedersen, Changing Women, Changing History: A Bibliography of the History of Women in Canada (Ottawa: Carleton University Press, 1996).

35 For a history of the Ontario Women's History Network, see Rose Fine-Meyer, "The Ontario Women's History Network: Linking Teachers, Scholars, and History Communities," in Feminist History in Canada, ed. Carstairs and Janovicek. For information about the Canadian Committee on Women's History, see http:// chashcacommittees-comitesa.ca/ccwh-cchf/.

36 Jane S. Gaskell, Arlene Tigar McLaren, Marta Danylewycz, and Alison I. Griffith, eds., Women and Education (Calgary: Detselig, 1991); Lara Campbell, Tamara Myers, and Adele Perry, eds., Rethinking Canada: The Promise of Women's History, 7th ed. (Don Mills, ON: Oxford University Press Canada, 2016).

37 Wendy Kohli, Feminism and Educational Research (New York: Rowman \& Littlefield, 2012), 5.

38 Peggy Bristow, Dionne Brand, Linda Carty, Afua P. Cooper, Sylvia Hamilton, and Adrienne Shadd, 'Were Rooted Here and They Can't Pull Us Up': Essays in African Canadian Women's History (Toronto: University of Toronto Press, 1994).

39 Adele Perry, "James Douglas, Amelia Connolly and the Writing of Gender and Women's History," in Feminist History in Canada, ed. Carstairs and Janovicek.

40 The panel included professors Rebecca Coulter from the University of Western Ontario and Dolana Mogadime from Brock University, Linda Kalafatides, a teacher with the Toronto District School Board, and Sarah Ghabrial, a member of the Miss G project. Beginning in 2005, five women friends, all students at the University of Western Ontario, lobbied the Ontario Ministry of Education to develop a secondary school course that focused on women and gender studies, arguing that university was too late to address issues of gender inequity. Called "The Miss G Project for Equity in Education," they launched a campaign of letters, phone calls, and postcards (interview by author with a member of the Miss G project, April 2010).

41 Catherine Porter, "Ontario Schools Will Offer Gender Studies, Thanks to Five Young Women," Toronto Star, April 23, 2013, https://www.thestar.com/news/gta/2013/04/26/ ontario_schools_will_offer_gender_studies_thanks_to_five_young_women_porter. html.

42 For Canadian programs, see http://www.wgsrf.com/academic-womens-studies.html; for a definition of gender studies, see Pearson and Rooke, "Gender Studies and Teacher Education: A Proposal," Canadian Journal of Education 18, no. 4 (1993), 416. Pearson defines gender studies in the following way: "Gender as a category of analysis seeks to understand how men and women's experiences are linked, in an inclusive vision of human dynamics based on notions of difference and diversity, not generalization and sameness."

43 Interviews with the course writing team by author, Toronto, 2010.

44 Ontario Ministry of Education, Gender Studies, grade 11 (HSG3M), Social Sciences and Humanities, grades 9-12 (Toronto: Ministry of Education, 2013), 58-69, http:// www.edu.gov.on.ca/eng/curriculum/secondary/ssciences9to122013.pdf.

45 Interview by author with ministry representatives, Toronto, February 2010.

46 Ontario Ministry of Education, Gender Studies, Grade 11 (HSG3M), 58-69.

47 Ontario Ministry of Education, Social Studies, History, and Geography, 2013, 8, http:// www.edu.gov.on.ca/eng/curriculum/elementary/sshg18curr2013.pdf and http:// historicalthinking.ca/historical-thinking-concepts. 
48 See http://thenhier.org/. THEN/HiER is the first pan-Canadian organization devoted to promoting - and improving - history teaching and learning. See also Peter Seixas and Tom Morton, The Big Six Historical Thinking Concepts (Toronto: Nelson, 2012).

49 For example, Scott Pollock's doctoral research includes an analysis of gender and student conceptions of historical significance. One of his preliminary findings from a female-only school, with a higher-than-usual concentration of women's history content, was active resistance to identifying women actors as historically significant. The reasons spanned from anti-feminist stances to perceptions that the Canadian narrative was more about men (for example, world wars, the Great Depression). See Scott Pollock, “'But, Those Sorts of Issues Aren't Relevant Anymore': Gender and Historical Significance," presented at the Canadian Society for the Study of Education, Ryerson University, May 2017.

50 Ontario Ministry of Education, Canadian and World Studies, 2015, grade 11-12, 54.

51 Ontario Ministry of Education, Canadian and World Studies, 2013, grades 9-10, 112-114.

52 Kimberly Crosby-Hillier, "Women and Educational Leadership: Exploring the Experiences of Current and Aspiring Female Educational Administrators" (M.Ed. thesis, University of Windsor, 2012), 8-9, http://scholar.uwindsor.ca/cgi/viewcontent. cgi? article $=1242 \&$ context=etd. Crosby-Hillier notes: "During the 2004-2005 school year approximately 8,000 men and 7,000 women were principals at elementary and secondary schools in Canada. At the elementary school level, female principals accounted for $53 \%$ of principals while men accounted for $68 \%$ of secondary school principal positions. Additionally, although women hold approximately three in four teaching positions in Canada, only one in five women are superintendents (Statistics Canada, 2008)."

53 See, for example, Jaqueline Kennelly and Kristina R. Llewellyn, "Educating for Active Compliance: Discursive Constructions in Citizenship Education," Citizenship Studies 15, no. 6-7: 897-914.

54 See Brittany Luby and Kathryn Labelle, "Cooperative Education at the Day School on Dalles 38C Indian Reserve, 1890-1910," in Ontario History 152, no. 1 (Spring 2015): 88-110, and M. Goulet and K. Goulet, Teaching Each Other: Nehinuw Concepts \& Indigenous Pedagogies (Vancouver: UBC Press, 2014).

55 Coulter, "Gender Equity and Schooling," 433-452.

56 The year 2020 will be the 50th anniversary of the RCSW, yet not all the recommendations have been fully addressed. Women are underrepresented in political and economic positions of power, and much work is needed to address visible minority and Indigenous women's rights. Black Lives Matter and the Me-Too movements are a call to action, making public the issues of sexual harassment, violence against women, and systemic racism. Part of the discrimination begins in the omission or "othering" of women in resources used in schools. 